$$
\begin{aligned}
& =\int_{\sigma_{1}}^{\sigma_{2}} \boldsymbol{E}_{\sigma} d \sigma=\int_{\sigma_{2}}^{\sigma_{1}} E_{\lambda} \sigma^{-2} d \sigma \\
& =\int_{v_{1}}^{\nu_{2}} E_{v} d \nu=\int_{v_{2}}^{v_{1}} E_{\lambda} c \nu^{-2} d \nu
\end{aligned}
$$

分光放射照度の測定結果から放射照度を求めるには， 測定值をディジタル化しておいてからマイクロコンピュ 一タ積算して求めたり，グラフにプロットしたものの面 積をプラニメータで求めてそれから計算したりする.

もしもポリマーの光劣化の作用スペクトルがわかって いる場合には，上記積分式中に作用スペクトルを掛ける ことによって有効放射照度を求められる。

ポリマーの暴露試験での環境モニター量としては，上

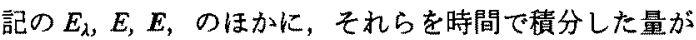
直接測定されることがある(例えば積算照度計と呼ばれ る計器の場合)， $E や \boldsymbol{E}$ を“dose rate”とするとその時 間積分值は“dose”である、日光の場合，全光放射の dose rate $\left(\mathrm{W} \cdot \mathrm{m}^{-2}\right)$ を日射と呼び, dose $\left(\mathrm{J} \cdot \mathrm{m}^{-2}\right)$ を日射 量と呼ぶ。放射照度については, doseについて一般に 通用する名称がないので，ここでは放射露光量としてお く. 一般にポリマーの光劣化速度は放射照度には正比例 せず，放射照度の0.5〜 1 乘に比例し，この指数は更に 波長によって変るようである.1 乗に比例する場合には 放射露光量のモニターが役立つが，そうでない場合には 放射照度のほうが役立つので，もし放射露光量しか求め られない場合には，暴露時間で割って平均放射照度を求 めてそれを利用するほうがよい，劣化に対する温度の影 響をArrhenius 式を利用して考える場合にも放射露光量 よりも放射照度が役立つ。

\section{4、まと め}

高分子材料の耐天候性評価のための暴露試験におい て，モ二ターすべき光に関する物理量については，高分 子分野についてはもちろんのこと，専門の照明工学分野 でも体系的に定義されていないので，考えられるすべて の量を定莪してそれらの相互関係を求めた。
1、単位時間中に単位面積の暴露試料面に照射される 単位波長間隔，単位波数間隔，あるWは単位振動数間隔 の光放射のエネルギー又は光子量をすべて “分光放射照 度”とする（微分量である）。

2. 分光放射照度をそれぞれ波長，“波数，振動数で積 分した量を“放射照度”とする(輝線スペクトル1本は 分光放射照度ではなく放射照度である)。

3. 現在むつとも一般的に使用されているのがエネル ギーを用い波長を用い，しかも非SIの分光放射照度 $\mathrm{W} \cdot \mathrm{m}^{-2} \cdot \mathrm{nm}^{-1}$ であるが，ここではSIに換算してW. $\mathbf{m}^{-3}$ とした.

4. 放射照度の時間積分值を放射露光量とした。

5. 高分子材料の暴露試験においては，これらの中の どの量を測定しているのかを理解しながらモニターしな ければならない。

\section{あとがき}

この研究は，高分子材料の耐天候性試験方法に関する 研究の一部である。

女 献

1）峰松陽一：日ゴム協誌，58, 33 (1985)

2) JIS Z 8202 量記号, 単位記号及び化学記号

3）羽生光宏, 鈴木 守, 長坂武彦: 電総研研究報告 [830] 1-175 (Jan. 1983), p. 99, June 22, 1979のデータ

\section{〔付 録〕}

太陽光の水平面での分光放射照度 $E_{\lambda}$ の測定結果が羽 生ら゙)によって報告されている。これを $E_{\sigma}, E_{v}, E_{\lambda}, E_{\sigma}$ ， Evに換算した例を付表及び付図に示す，符号がマイナ スのものは, $\sigma や v か ゙ \lambda の$ 逆数のため $\lambda$ とは大小関係が 逆転しているためである. $\sigma$ 使った場合とv使った 場合の図は相対的な形が同じになるので波数 $\sigma$ を使っ た場合のみを図示してある。

\title{
訂正のお知らせとお詑び
}

\begin{tabular}{|c|c|c|c|c|c|c|}
\hline 巻 & 号 & ページ & 行 & $\therefore$ & $\therefore$ & 正 \\
\hline \multirow[t]{2}{*}{ Vol. 58} & No. 1 & p. 34 & 右个12 & 式(1) & & 式(2) \\
\hline & & & & 式(2) & & 式(1) \\
\hline Vol. 58 & No. 3 & p. 139 & $\begin{array}{l}\text { 左 } \uparrow 10 \\
\text { 左 } \uparrow 9\end{array}$ & $\begin{array}{l}\text { エピクロルヒ } \\
\text { 耐熱珄 }\end{array}$ & ドリンゴム & 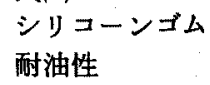 \\
\hline
\end{tabular}

本誌の揭載文について下記のとお゙り誤植がございましたので，ここに訂正してお詑びいたします. 